Article

\title{
Biological Evaluation of Uridine Derivatives of 2-Deoxy Sugars as Potential Antiviral Compounds against Influenza A Virus
}

\author{
Ewelina Krol $^{1, *}$, Ilona Wandzik ${ }^{2}$, Martyna Krejmer-Rabalska ${ }^{1}$ (D) and Boguslaw Szewczyk ${ }^{1}$ \\ 1 Department of Recombinant Vaccines, Intercollegiate Faculty of Biotechnology of University of Gdansk \\ and Medical University of Gdansk, Abrahama 58, 80-307 Gdansk, Poland; \\ martyna.krejmer@biotech.ug.edu.pl (M.K.-R.); szewczyk@biotech.ug.gda.pl (B.S.) \\ 2 Department of Organic Chemistry, Bioorganic Chemistry and Biotechnology, Faculty of Chemistry, \\ Silesian University of Technology, Krzywoustego 8, 44-100 Gliwice, Poland; Ilona.Wandzik@polsl.pl \\ * Correspondence: ewelina@biotech.ug.gda.pl; Tel.: +48-58-523-63-83
}

Received: 28 June 2017; Accepted: 30 July 2017; Published: 4 August 2017

\begin{abstract}
Influenza virus infection is a major cause of morbidity and mortality worldwide. Due to the limited ability of currently available treatments, there is an urgent need for new anti-influenza drugs with broad spectrum protection. We have previously shown that two 2-deoxy sugar derivatives of uridine (designated IW3 and IW7) targeting the glycan processing steps during maturation of viral glycoproteins show good anti-influenza virus activity and may be a promising alternative approach for the development of new anti-influenza therapy. In this study, a number of IW3 and IW7 analogues with different structural modifications in 2-deoxy sugar or uridine parts were synthesized and evaluated for their ability to inhibit influenza A virus infection in vitro. Using the cytopathic effect (CPE) inhibition assay and viral plaque reduction assay in vitro, we showed that compounds 2 , 3, and 4 exerted the most inhibitory effect on influenza virus A/ostrich/Denmark/725/96 (H5N2) infection in Madin-Darby canine kidney (MDCK) cells, with 50\% inhibitory concentrations $\left(I C_{50}\right)$ for virus growth ranging from 82 to $100(\mu \mathrm{M})$ without significant toxicity for the cells. The most active compound (2) showed activity of $82 \mu \mathrm{M}$ with a selectivity index value of 5.27 against type A (H5N2) virus. Additionally, compound 2 reduced the formation of HA glycoprotein in a dose-dependent manner. Moreover, an analysis of physicochemical properties of studied compounds demonstrated a significant linear correlation between lipophilicity and antiviral activity. Therefore, inhibition of influenza A virus infection by conjugates of uridine and 2-deoxy sugars is a new promising approach for the development of new derivatives with anti-influenza activities.
\end{abstract}

Keywords: influenza A virus; antiviral compounds; uridine; 2-deoxy sugars; glycosylation inhibition

\section{Introduction}

Influenza is a highly contagious acute viral infection with high morbidity and mortality rates in humans and animals worldwide [1]. About $20 \%$ of the world's population is infected by the virus, which results in around 250,000-500,000 deaths annually [2]. The H1N1 and H3N2 influenza virus subtypes are the most prevalent and the main reason for several recent pandemics in humans, including the 2009 H1N1 pandemic with high morbidity. Vaccines and prophylaxis with antiviral drugs are currently two main strategies used to control influenza infections. Vaccination strategies are the best method of prevention. However, they have to be updated regularly to account for antigenic changes of the viral glycoproteins. Moreover, vaccines are only around 50\% effective in the elderly, where most of the mortality occurs. Additionally, in the case of an epidemic or pandemic caused by a new strain, development of an effective vaccine requires from three to six months using the conventional 
egg-based method, which can be too slow to be effective against the spread of infection. Due to the lack of effectiveness of vaccines against rapidly emerging mutant viruses during seasonal epidemics and sporadic pandemics, antiviral drugs against influenza virus may represent the first line of defence, especially in the beginning of an epidemic until a suitable, effective vaccine becomes available.

Despite very intensive research for new antivirals, few compounds representing two classes of influenza virus inhibitors are currently available for clinical use: M2 ion-channel blockers (amantadine and rimantadine) $[3,4]$ and neuraminidase (NA) inhibitors (oseltamivir and zanamivir) $[5,6]$. Other NA inhibitors, like Laninamivir and Peramivir, have been approved in North Asia but are still in clinical trials in Europe and North America [7]. M2 inhibitors that prevent viral uncoating are active only against influenza A viruses [8]. Although both amantadine and rimantadine show strong anti-influenza activity, the rapid appearance of drug resistance in circulating virus strains restricts the use of such drugs for influenza prevention and treatment [9-11]. By blocking the release of newly formed viral particles, neuraminidase inhibitors prevent the spread of the influenza A and B viruses [12]. Despite the fact that the target site for NA inhibitors is relatively well conserved, a number of resistant mutations in the NA gene have arisen rapidly as a consequence of drug induced selective pressure [13-15]. In the USA, the number of oseltamivir-resistant H1N1 viruses quickly increased from $0.5 \%$ in 2006-2007 to $99 \%$ in the 2008-2009 season [16,17]. In Europe and North America, oseltamivir-resistant H1N1 viruses were also detected and are now widely circulating [18-20]. Moreover, highly pathogenic avian influenza strains such as H7N9 and H5N1, with the potential to cause a new influenza pandemic, are also resistant to oseltamivir [21]. The limitations of current drug therapy and the increasing emergence of multiple drug-resistant influenza strains calls for a new generation of broad-spectrum anti-influenza drugs with an alternative mode of action that would be effective against a wide array of influenza strains.

Hemagglutinin (HA) and NA are membrane glycoproteins abundant on the viral surface. They play an important role in the influenza virus life cycle and constitute important targets for anti-influenza drug design. HA is involved in viral entry. It interacts with host cell receptors containing sialic acids and plays a role in membrane fusion [22]. NA catalyzes the removal of sialic acids and releases the progeny viruses from the complexes with host proteins at late stages of infection [23,24]. Hemagglutinin and neuraminidase are highly $N$-glycosylated proteins. HA and NA contain three to nine and four potential $\mathrm{N}$-glycosylation sites, respectively $[25,26]$, and their number and types depends on the virus subtype and strain $[27,28]$. The most conserved $\mathrm{N}$-glycosylation occurs in the stalk region of the HA protein [29].

The composition of oligosaccharide chains in viral glycoproteins can be modulated by glycosyltransferases (GTs) during maturation. Alteration of glycosylation by effective inhibitors of GTs may affect viral survival. A number of natural products have been found to alter glycosylation, e.g., tunicamycin, which inhibits viral coat formation [30]. Recently, we have synthesized several compounds that were donor substrate analogues of GTs. These compounds can prevent glycosylation by occupying the active site of the enzyme [31-33]. They contain uridine moiety and mimic the uridine diphosphate (UDP)-sugar natural substrates. We have previously reported that two compounds from this series-2-deoxy sugar derivatives of uridine (IW3 and IW7) (Figure 1)—showed good anti-influenza virus activity in vitro with $\mathrm{IC}_{50}$ of 72 and $63 \mu \mathrm{M}$, respectively [34]. It was concluded that IW3 and IW7 block the influenza virus by targeting the glycan process during the synthesis of viral glycoproteins. We have shown that both compounds impaired maturation of influenza viral proteins by inhibiting the late step of $\mathrm{N}$-glycosylation process, which differs from the mechanism of currently used anti-influenza drugs.

In this study, a number of IW3 and IW7 analogues featuring different structural modifications in 2-deoxy sugar or uridine parts were synthesized and further evaluated for their antiviral activity against influenza A virus. The new data show that some of the synthesized compounds possess good antiviral activities in vitro and that some modifications improved the selectivity indexes compared to the previously described IW7 compound. 


\section{Results}

\subsection{Chemistry}

Recently, we reported that 2-deoxy sugar derivatives of uridine, compounds IW3 and IW7 (Figure 1), exhibited efficient inhibitory effects against H5N2 and H1N1 influenza A viruses in Madin-Darby canine kidney (MDCK) cells [34]. In the current work, we investigated the effect of various protecting groups on antiviral activity. The protections of hydroxyl groups in 2-deoxy sugar part, as well as hydroxyl groups in ribose part or uracil nitrogen, were applied. In a series of compounds, totally deprotected compounds were synthesized for comparison. Compounds 1-9 were synthesized in addition reactions of uridine acceptors to the double bond of glycals using the Falck-Mioskowski protocol [35]. The synthesis of compounds 5, 7, 8, and 9 was published in our previous reports [32,33], while the synthesis and structural data of compounds 1, 2, 3, 4, and $\mathbf{6}$ is presented in Supplementary Material Sections S1 and S2.
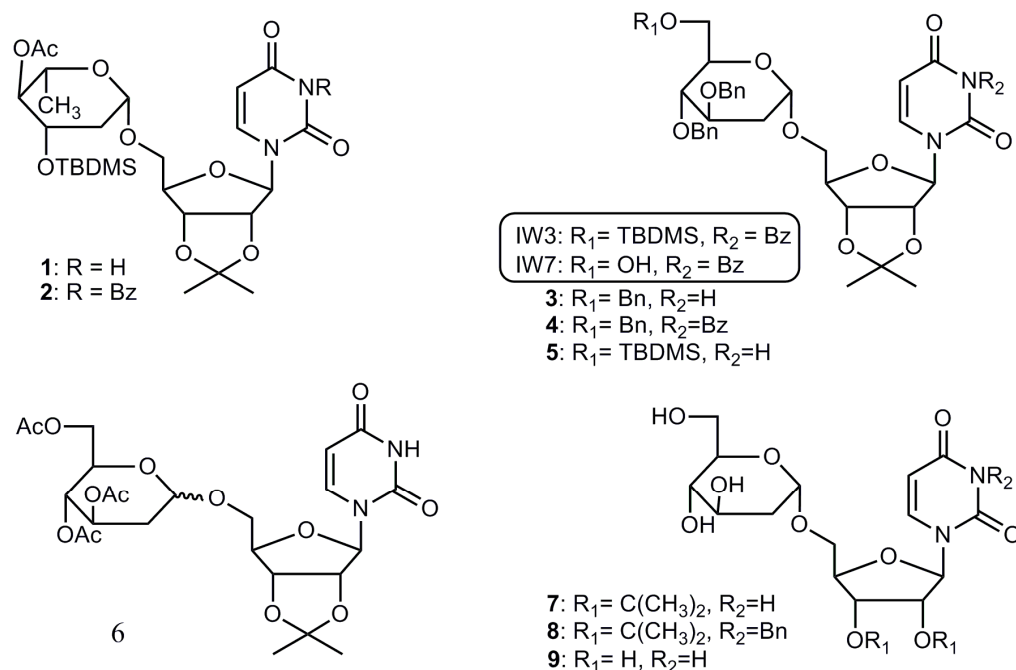

Ac - acetyl, Bz - benzoyl, Bn-benzyl, TBDMS - tert-butyldimethylsilyl

Figure 1. Structures of 2-deoxy sugar derivatives of uridine active against influenza A virus.

\subsection{Antiviral Activity of Newly Synthesized Compounds against Influenza A Virus}

The cytotoxicity of synthesized compounds in MDCK cells was first evaluated by non-radioactive cell proliferation assay (MTS). For each compound, $C_{50}$ values, corresponding to a $50 \%$ cytotoxic effect after $48 \mathrm{~h}$ of inhibitor treatment, were determined (Table 1). There was no cytotoxicity observed in cells treated with the highest concentrations of DMSO (solvent) used in the screening.

The antiviral activities of synthesized 2-deoxy sugar derivatives of uridine 1-9 against influenza virus A/ostrich/Denmark/725/96 (H5N2) were evaluated using cytopathic effect (CPE) inhibition assay and plaque reduction assay. Influenza A/ostrich/Denmark/725/96 virus causes a severe CPE in MDCK-infected cells including cell rounding, detachment and death. A reduction in influenza A virus-induced cytopathic effect after $24 \mathrm{~h}$ incubation indicated antiviral activity of the tested compounds. The initial results showed that all nine synthesized compounds exhibit low to high antiviral activity against influenza A virus. It was found that compounds 2, 3, and 4 significantly reduced the CPE caused by infection in MDCK cells, while the remaining compounds were less active. The CPE was reduced when appropriate doses of each compound were added to MDCK-infected cells, which suggests that all compounds were able to protect cells from virus-induced cell death. The example of the effect of compound 2 on CPE reduction is shown in Figure 2. 
Table 1. Cytotoxicity and antiviral activity of synthesized compounds against influenza A virus.

\begin{tabular}{ccccc}
\hline Compound & $\mathbf{M W}(\mathbf{g} / \mathbf{m o l})$ & $C_{\boldsymbol{5}_{\mathbf{0}}}(\boldsymbol{\mu M})^{\mathbf{a}}$ & $\mathbf{I C}_{\mathbf{5 0}}(\boldsymbol{\mu M})^{\mathbf{b}}$ & $\mathbf{S I}^{\mathbf{c}}$ \\
\hline $\mathbf{1}$ & 570 & 193 & $175 \pm 8.22$ & 1.10 \\
$\mathbf{2}$ & 674 & 432 & $82 \pm 6.81$ & 5.27 \\
$\mathbf{3}$ & 700 & 407 & $100 \pm 9.84$ & 4.07 \\
$\mathbf{4}$ & 804 & 480 & $99 \pm 5.23$ & 4.85 \\
$\mathbf{5}$ & 724 & 150 & $96 \pm 7.64$ & 1.56 \\
$\mathbf{6}$ & 556 & 620 & $575 \pm 17.18$ & 1.08 \\
$\mathbf{7}$ & 430 & 828 & $721 \pm 23.21$ & 1.15 \\
$\mathbf{8}$ & 520 & 669 & $346 \pm 10.53$ & 1.93 \\
$\mathbf{9}$ & 390 & 800 & $410 \pm 11.22$ & 1.95 \\
IW3 & 828 & 640 & $72 \pm 5.20$ & 8.89 \\
IW7 & 714 & 123 & $63 \pm 4.17$ & 1.95 \\
\hline
\end{tabular}

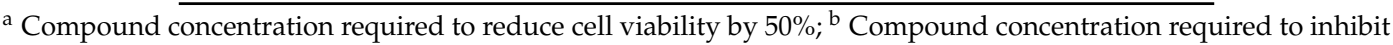
virus plaque production by $50 \%$; Data are mean values \pm S.D. from three independent experiments; ${ }^{c}$ Selectivity index calculated as ratio of $C C_{50}$ to $I C_{50}$.
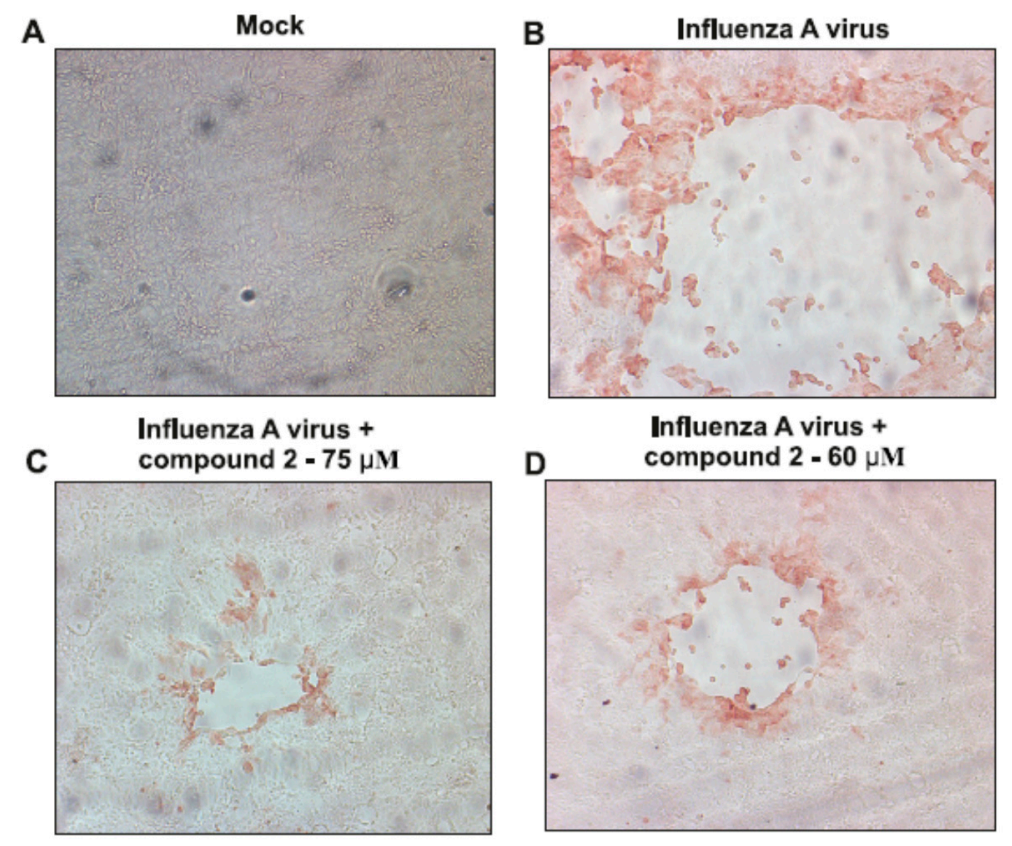

Figure 2. Reduction of influenza A virus-induced cytopathic effect by compound 2. Madin-Darby canine kidney (MDCK) cells were not-infected (A) or infected with influenza virus A/ostrich/ Denmark/725/96 (H5N2) (B-D). At $1 \mathrm{~h}$ p.i., the virus was removed and the cells were treated with $75 \mu \mathrm{M}(\mathbf{C})$ or $60 \mu \mathrm{M}$ (D) of compound 2 or left untreated (positive control-B). $24 \mathrm{~h}$ p.i., the inhibitory effect of compound 2 on virus replication was evaluated by immunostaining using a monoclonal anti-M1 antibody. Images under a Nicon Eclipse TE300 microscope (Nicon Corporation, Tokyo, Japan) at $100 \times$ magnification.

A plaque reduction assay was carried out to confirm the efficacy of tested compounds on influenza virus propagation and to measure the accurate $I C_{50}$ values. MDCK cells were infected with H5N2 influenza strain $(M O I=0.01)$ and incubated with overlay medium containing various concentrations of compounds 1-9. After three days, cells were immunostained with specific monoclonal anti-M1 antibody to measure the extent of viral infection. Oseltamivir carboxylate, an inhibitor of influenza neuraminidase, was used as a positive control. This compound displayed an $I C_{50}$ value of about $0.15 \mu \mathrm{M}$ and low cytotoxicity $\left(C_{50}>100 \mu \mathrm{M}\right)$ in our assay. 
The $I C_{50}$ values for the most active compounds 2,3 , and 4 were in range of $82-100 \mu \mathrm{M}$ (Table 1). One of the least polar compound 2 exhibited the highest activity. The average size and plaque number in compound 2-treated cells were markedly reduced in a dose-dependent manner (Figure 3).
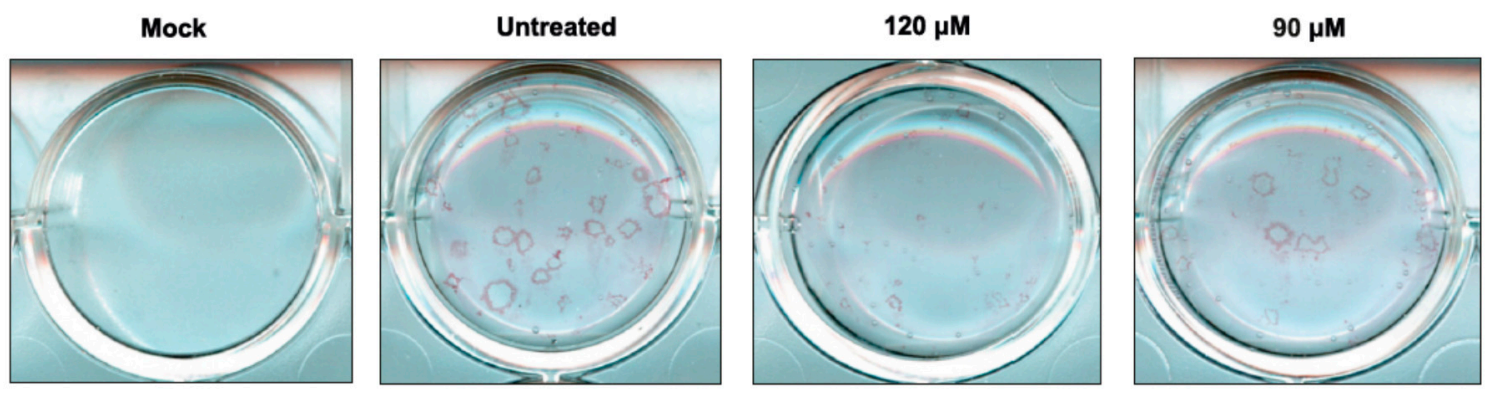

Figure 3. Dose-dependent reduction of influenza A viral plaque formation after treatment with compound 2. MDCK cells were infected with influenza virus A/ostrich/Denmark/725/96 (H5N2) or mock infected. At $1 \mathrm{~h}$ p.i., the virus was removed and the cells were incubated with overlay medium containing compound 2. 3 days p.i., cells were fixed and influenza A virus plaques were detected by immunostaining with specific, monoclonal anti-M1 antibody.

The analysis showed that the presence of benzoyl group in the uracil part in compound 2 significantly improved antiviral effect $\left(I C_{50}=82 \mu \mathrm{M}\right)$ and reduced the cytotoxicity in comparison to compound $1\left(I C_{50}=175 \mu \mathrm{M}\right)$. This is in contrast to 2-deoxy glucose series where no significant increase of activity was observed for compound $4\left(I C_{50}=99 \mu \mathrm{M}\right)$ in comparison with compound 3 $\left(I C_{50}=100 \mu \mathrm{M}\right)$. Different protection of hydroxyl groups in 2-deoxy-glucose part did not affect the activity when nonpolar protective groups were introduced. The antiviral activity was slightly reduced compared to compound 2. Significant loss of activity was observed for compound 6 (IC $\left.C_{50}=575 \mu \mathrm{M}\right)$ containing relatively polar per-O-acetylated 2-deoxy-glucose part. Moreover, the similar effect of reduced activity was noticed for compounds 7-9 containing totally deprotected hydroxyl groups in 2-deoxy-glucose part ( $I C_{50}$ values of 721,346 and $410 \mu \mathrm{M}$, respectively), although the cytotoxicity of these compounds was low. It seems that lipophilicity of studied compounds might be a key parameter influencing the viral activity.

\subsection{Quantitative Structure-Activity Relationship Analysis between Antiviral Activity and Lipophilicity}

Molecular lipophilicity is a key factor in the description of pharmacokinetic properties of a drug and its interaction with molecular targets. This physicochemical descriptor characterizes the affinity of a drug for lipophilic environment. It is usually defined as the partition coefficient $(\mathrm{P})$ between n-octanol and water. In most cases this value is presented as $\log P$. The experimental $\log P$ by direct shake-flask method can not always be determined for some compounds due to technical reasons. Instead, calculated $\log P$ or other experimental lipophilicity parameters could be determined. Theoretical $\log P$ values for the target compounds can be calculated using different algorithms. Recently, we have showed a good agreement between experimental data and theoretical $\log P$ values for twenty one uridine derivatives [36]. A good agreement was obtained when $X \operatorname{LogP3}$ algorithm [37] was applied, thus in this study XlogP3 have been calculated for structures 1-9.

As an alternative to calculated $\log \mathrm{P}$, different experimental lipophilicity parameters, e.g., the chromatographic lipophilicity index $\left(R_{\mathrm{Mw}}\right)$ might be used. It was reported that there is a strong linear relationship between $R_{\mathrm{Mw}}$ parameter and experimental $\log P$ for a certain family of chemically related compounds [38]. Experimental lipophilicity parameters $R_{\mathrm{Mw}}$ of studied compounds were determined by reverse phase thin layer chromatography (RP-TLC) according to the method previously described [36] (Supplementary Material Section S3). It was possible to determine $R_{\mathrm{Mw}}$ 's for all compounds, except for compound 9 because of very low lipophilicity. In this work, experimentally 
obtained $R_{\mathrm{Mw}}$, and computed $\mathrm{X} \log \mathrm{P} 3$ data (Table 2) were analyzed independently in order to find relationships between lipophilicity and antiviral activity against influenza A virus expressed as $p\left[I C_{50}\right]$.

Table 2. Antiviral activity and lipophilicity parameters of 2-deoxy sugar derivatives of uridine.

\begin{tabular}{cccc}
\hline Compound & $p\left[I C_{50}\right]$ & $R_{\mathbf{M w}}$ & $X \log P 3$ \\
\hline $\mathbf{1}$ & 3.76 & 5.83 & 2.04 \\
$\mathbf{2}$ & 4.09 & 6.74 & 3.66 \\
$\mathbf{3}$ & 4.00 & 6.40 & 3.63 \\
$\mathbf{4}$ & 4.00 & 7.58 & 5.30 \\
$\mathbf{5}$ & 4.01 & 8.06 & 4.94 \\
$\mathbf{6}$ & 3.24 & 2.32 & -0.74 \\
$\mathbf{7}$ & 3.14 & 0.19 & -1.91 \\
$\mathbf{8}$ & 3.46 & 2.09 & -0.24 \\
$\mathbf{9}$ & 3.39 & - & -3.15 \\
\hline
\end{tabular}

$p\left[I C_{50}\right]=-\log \left[I C_{50}\right]$, where $\mathrm{IC}_{50}$ is expressed in mole $/ \mathrm{L} ; R_{\mathrm{Mw}}$-The chromatographic lipophilicity index determined experimentally by RP TLC; XlogP3-Calculated partition coefficient.

A good linear correlation between the antiviral activity of the compounds 1-9 and their lipophilicity was observed. More hydrophobic compounds, characterized by higher $R_{\mathrm{Mw}}$ or $X \log P 3$ values had increased antiviral activity, which can be expressed by Equations (1) and (2). Better fit was observed between activity and experimental $R_{\mathrm{Mw}}$ parameter $(R=0.96)$ in comparison with calculated $X \log P 3(R=0.92)$. The fitness of the model was checked by the coefficient of determination $(R 2)$ and standard error of the regression (se). All statistical parameters are described in methods.

$$
\begin{gathered}
p\left[I C_{50}\right]=3.091( \pm 0.080)+0.126( \pm 0.014) \times R_{\mathrm{Mw}} \\
n=8, R=0.96, R^{2}=0.93 s_{e}=0.11, \mathrm{~F}(1,6)=71.6, p=0.0001 \\
p\left[I C_{50}\right]=3.505( \pm 0.057)+0.112( \pm 0.017) \times X \log P 3 \\
n=9, R=0.92, R^{2}=0.85 s_{e}=0.15, \mathrm{~F}(1,7)=41.3, p=0.0003
\end{gathered}
$$

It was found that compounds with high antiviral activity have to contain hydrophobic fragments, e.g., benzyl, benzoyl, tert-butyldimethylsilyl or isopropylidene groups. The most active compounds from the series were the most lipophilic compounds $\mathbf{2}-\mathbf{4}$, conversely the least active compounds were the most polar derivatives 7-9 containing totally deprotected 2-deoxy sugar units.

\subsection{Inhibitory Effects of Compound 2 on Different Stages of Viral Replication Cycle}

In the light of promising activity of compound 2, the activity of this inhibitor was more thoroughly examined. To determine the stages by which compound 2 acts during the influenza A virus life cycle, a time-of-addition studies were performed according to the scheme: overnight before virus adsorption (I), during virus adsorption for $1 \mathrm{~h}$ (II) or post-virus adsorption for $72 \mathrm{~h}$ (III). After incubation in case of I and II, the inhibitor was removed and cells were grown for $72 \mathrm{~h}$ in fresh medium. The analysis showed that compound $\mathbf{2}$ inhibited the propagation of influenza virus only when it is added to the cells after viral infection (Figure 4). The obtained results strongly suggested that this compound target post-adsorption steps of influenza A virus replication cycle. 


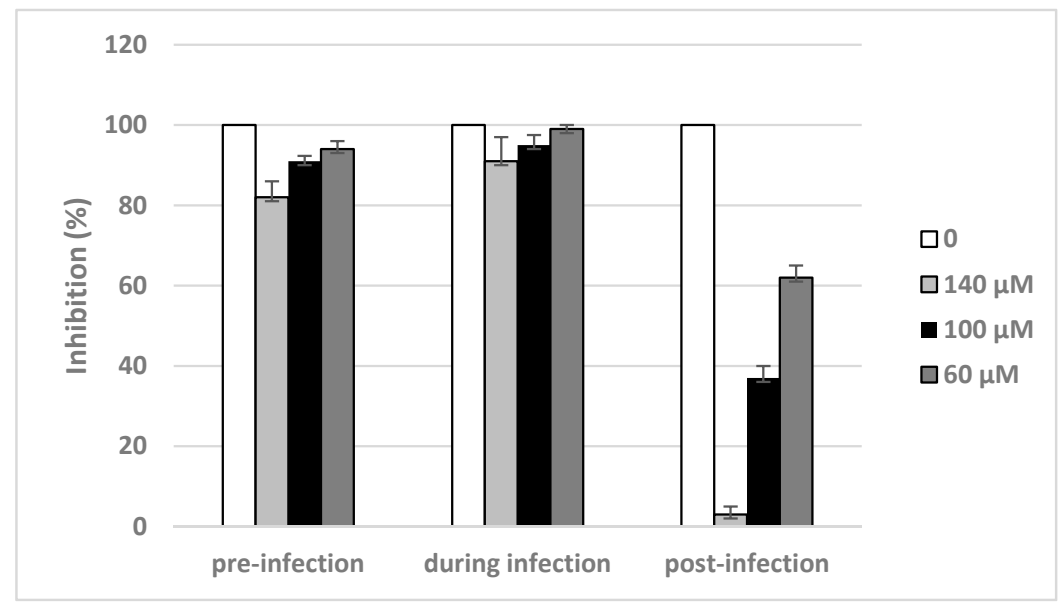

Figure 4. Inhibitory effects of compound 2 on different stages of viral infection. Compound 2 was added to MDCK cells overnight before adsorption (I), during viral adsorption for $1 \mathrm{~h}$ (II) or post-viral adsorption for $72 \mathrm{~h}$ (III). A/ostrich/Denmark/725/96 (H5N2) infected MDCK cultures were incubated for $72 \mathrm{~h}$. The cell viability was evaluated by MTS assay.

\subsection{Inhibitory Effect of Compound 2 on Influenza A Protein Synthesis}

We have previously shown that two synthesized by us 2-deoxy sugar derivatives of uridine (compounds IW3 and IW7), belonging to $\mathrm{N}$-glycosylation inhibitors, effectively blocked influenza A virus propagation by affecting the synthesis of viral glycoproteins [34]. Due to the fact that the new compounds were synthesized as derivatives of IW3 and IW7 compounds, we wanted to check the effects of further modifications of these compounds on viral glycoprotein synthesis. Compound 2 was found to be the most active in the series, therefore this compound was selected for further investigation. To explore the inhibitory effect on the replication of influenza A virus, the influence of compound 2 on protein synthesis was determined. Western blotting analysis showed that the yield of HA protein in cells infected with pandemic human influenza A/H1N1 virus was reduced by compound 2 in a dose-dependent manner (Figure 5). These results were in agreement with the results obtained previously for IW3 and IW7 compounds. Furthermore, with the highest doses of compound 2, the mature form of HA protein were not detected. Moreover, we were not able to detect the unglycosylated or underglycosylated forms of HA protein, probably due to the fact that incorrectly matured proteins are rapidly degraded. The consistent expression levels of $\beta$-actin indicated that the tested doses of compound 2 did not affect the levels of host cellular proteins.

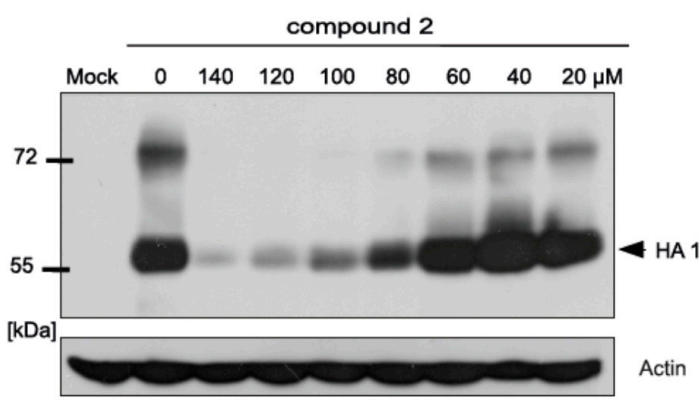

Figure 5. Effect of compound 2 on influenza A virus HA glycoprotein synthesis. Madin-Darby canine kidney cells (MDCK) cells were infected with influenza A virus (pandemic human A/H1N1 virus) and treated with various concentrations of compound 2. At $48 \mathrm{~h}$ post-infection, cells were lysed, and proteins were separated by SDS-PAGE ( $10 \%$ polyacrylamide) under reducing conditions. Western blot analysis was performed using the specific rabbit polyclonal serum anti-sHA and anti- $\beta$-actin monoclonal antibodies. HA: Hemagglutinin. 


\section{Discussion}

Influenza is an acute respiratory illness with high morbidity and mortality globally. Some circulating influenza subtypes can cause massive global epidemics, causing panic in human population. Anti-influenza treatment with current antivirals often leads to drug resistance in circulating influenza strains, and this fact calls for new drugs targeting alternative steps of viral development. Numerous herbs and their bioactive ingredients started to play role as an important source of therapeutic agents in recent years [39,40]. Even though some of them showed good antiviral activity in vitro, most of their antiviral activity is still associated with the influenza viral replication process. However, there are some reports demonstrating the antiviral activity of natural compounds via interaction with viral structural proteins like hemagglutinin [41,42].

Hemagglutinin (HA) and neuraminidase (NA) are enveloped proteins of the influenza virus that mediate viral entry and release. HA interacts with host cell receptors containing sialic acids facilitating virus entry and plays a role in membrane fusion [22]. NA is a sialidase catalyzing the removal of sialic acids from the complexes between progeny virus and host cell components which allows for the release of newly formed viruses [23]. The roles of these proteins in the influenza virus life cycle make them prospective candidates for novel antiviral strategies. Both NA and HA are glycoproteins that contain 4 and 3-9 N-linked glycan chains, respectively [25,26].

$\mathrm{N}$-glycosylation is one of the most important steps in maturation of viral proteins. It is essential for the stability and correct folding of glycoproteins and it also strongly influences other important biological functions. It has been found that the arrest of glycosylation of viral glycoproteins by different natural or chemically synthesized inhibitors usually results in antiviral effects [43-46]. The antibiotic tunicamycin is one of the best known inhibitors of $\mathrm{N}$-glycosylation process with significant antiviral activity. However, its high toxicity in vivo prevents the use of this antibiotic as a therapeutic agent $[47,48]$.

This significant antiviral activity of tunicamycin encouraged us to synthesize compounds mimicking the tunicamycin structure and to check their antiviral activity. In our previous studies, we have demonstrated that two compounds belonging to tunicamycin derivatives-uridine derivatives of 2-deoxy sugars (named IW3 and IW7) - possess significant antiviral activity against classical swine fever virus [49]. We have shown that these two compounds affect protein glycosylation similarly to tunicamycin, but they are significantly less toxic. Moreover, our other previous report consistently confirmed that both IW3 and IW7 compounds, due to the universal mechanism of action, were also active against influenza A virus $\mathrm{H} 5 \mathrm{~N} 2$ and $\mathrm{H} 1 \mathrm{~N} 1$ strains at non-toxic concentrations targeting the maturation of viral proteins [34]. This unique effect of both compounds on the HA protein prompted our further studies focused on the examination of the effect of a wide array of other synthesized compounds on the yield of influenza virus.

In the current study, nine novel 2-deoxy sugar derivatives of uridine were synthesized and screened for their antiviral activity against influenza A virus. We showed that compounds 2, 3 , and 4 exerted the most significant inhibitory effect on in vitro influenza virus infection in the series evaluated in CPE inhibition assay as well as in the plaque reduction assay in MDCK cells using A/ostrich/Denmark/725/96 (H5N2) virus. Our analysis showed that the antiviral activity of tested compounds is enhanced by the addition of hydrophobic fragments, e.g., benzyl, benzoyl, tert-butyldimethylsilyl, or isopropylidene groups. The data showed that some modifications improved the selectivity indexes of new synthesized compounds compared to the previously published IW7 compound (Table 1). Linear correlation of lipophilicity and antiviral activity was observed: the more hydrophobic substituents increased antiviral activity (Equations (1) and (2)). It might be hypothesized that the antiviral activity is not specific, and only the highly lipophilic compounds could cross cell membranes; thus, the activity is related to pharmacokinetic aspects. Alternatively, hydrophobic interactions between the highly lipophilic compounds and receptors might occur. One of the most lipophilic, compound 2, with the presence of benzoyl group in the uracil part, showed the highest antiviral activity against $\mathrm{H} 5 \mathrm{~N} 2$ influenza A virus strain among all tested compounds, with an $I C_{50}$ 
value of $82 \mu \mathrm{M}$ and low cytotoxicity $\left(C_{50}\right.$ of $\left.432 \mu \mathrm{M}\right)$ as observed in plaque reduction assay (Figure 3). Our studies have confirmed that the mechanism of the antiviral activity of compound 2 against influenza virus may be the same as was shown for IW3 and IW7 compounds. Greater activity of compound 2 was observed when this inhibitor was added after viral adsorption, which suggests that it acts predominantly on the intracellular steps of the viral replication cycle (Figure 4). Moreover, we have examined the effect of this new lead compound on the synthesis of viral proteins. These studies indicated that the reduction in influenza virus production (Figures 2 and 3) can be associated with the inhibition of viral glycoprotein synthesis in infected cells. We have demonstrated that compound 2 caused a dose-dependent decrease of HA glycoprotein production (Figure 5). However, the underglycosylated forms of HA were not detected, suggesting that such incorrectly matured polypeptides are degraded very quickly in host cells.

The role of $\mathrm{N}$-glycosylation process in the life cycle of influenza virus has been shown in many reports [50-55]. For both HA and NA proteins, the number and location of glycans on the polypeptide chain are crucial for biological activity of these proteins. The importance of tip glycans of HA was reported by Wagner and coworkers [54]. It was found that the lack of one or two glycans led to the significant arrest of the growth of HA mutants in cell culture. Also, as shown by Saito and Yamaguchi, the transport of NA to the host cell surface is impaired by the inhibition of $\mathrm{N}$-glycosylation resulting in the restrictions on the release of viral progeny [53]. In light of the presented data, the new studies in the search for inhibitors targeting viral glycoprotein maturation are highly justified.

In summary, the presented data showed that 2-deoxy sugar derivatives of uridine may constitute a novel class of inhibitors with mechanism of action different from currently used anti-influenza drugs. The study demonstrated that some of synthesized compounds demonstrate good antiviral activities in vitro and that some modifications improved the selectivity indexes compared to the previously published IW7 compound. Overall, our data suggest that further modification of the compound 2 could result in hit compounds endowed with potentially increased antiviral activity.

\section{Materials and Methods}

\subsection{Cells, Viruses and Antiviral Compounds}

Madin-Darby canine kidney cells (MDCK; ATCC ${ }^{\circledR}$ CCL-34 ${ }^{\mathrm{TM}}$ ) were grown in Dulbecco's Modified Eagle's Medium (D-MEM) (Sigma-Aldrich, St. Louis, MI, USA), containing 10\% heat-inactivated fetal bovine serum (FBS), $2 \mathrm{mM}$ L-glutamine, $0.2 \%$ bovine serum albumin, $25 \mathrm{mM}$ HEPES buffer, $100 \mathrm{U} / \mathrm{mL}$ penicillin, $100 \mu \mathrm{g} / \mathrm{mL}$ streptomycin, at $37{ }^{\circ} \mathrm{C}$ under $5 \% \mathrm{CO}_{2}$.

The avian influenza virus A/ostrich/Denmark/725/96 (H5N2) was obtained from the Department of Poultry Diseases, National Veterinary Research Institute, Pulawy, Poland. Isolate $32 \mathrm{U}$ of the pandemic human influenza A/H1N1 virus) from the collection of the Department of Recombinant Vaccines, University of Gdansk, Poland, was also used in this study. Influenza A viruses were grown in MDCK cells in the presence of $2 \mu \mathrm{g} / \mathrm{mL}$ TPCK (L-1-Tosylamide-2-phenylethyl chloromethyl ketone) — trypsin (Sigma-Aldrich, St. Louis, MI, USA). Virus titers were determined by plaque assay.

The stocks solutions of synthesized compounds were prepared by dissolving the reagents in dimethyl sulfoxide (DMSO) and stored in $-20{ }^{\circ} \mathrm{C}$ until future use. Oseltamivir carboxylate was purchased from Santa Cruz Biotechnology (Heidelberg, Germany).

\subsection{Cell Viability Assay}

MDCK cell viability was determined by CellTiter $96 \mathrm{AQ}_{\text {ueous }}$ non-radioactive cell proliferation assay (MTS) (Promega: Madison, WI USA) as described previously [34]. Stock solutions of synthesized compounds were prepared by dissolving in dimethyl sulfoxide (DMSO) and stored at $-20{ }^{\circ} \mathrm{C}$. The half-maximal cytotoxic concentration $\left(C C_{50}\right)$ was calculated as the compound concentration required to reduce cell viability by $50 \%$. 


\subsection{Cytopathic Effect (CPE) Inhibition Assay}

Antiviral activity was evaluated in cytopathic effect (CPE) inhibition assay and plaque reduction assay by methods reported previously [34]. Briefly, in the CPE inhibition assay, confluent monolayers of MDCK cells, seeded in 6-well plates, were infected with influenza virus A/ostrich/Denmark/725/96 (H5N2) for $1 \mathrm{~h}$ at $37^{\circ} \mathrm{C}$. The virus was removed by washing with serum-free medium, and cells were overlaid with fresh serum-free medium supplemented with $2 \mu \mathrm{g} / \mathrm{mL}$ TPCK-trypsin and various concentrations of inhibitors. After $24 \mathrm{~h}, \mathrm{CPE}$ was determined both by MTS assay and by immunostaining with a monoclonal anti-M1 antibody as described in plaque reduction assay.

\subsection{Plaque Reduction Assay}

Confluent monolayers of MDCK cells in 12-well plates were inoculated with influenza A virus for $1 \mathrm{~h}$ at $37^{\circ} \mathrm{C}$. After removal of the virus, the cells were washed with serum-free medium and overlaid with fresh serum-free medium supplemented with 1.2\% Avicel (FMC BioPolymer, Philadelphia, PA, USA), $2 \mu \mathrm{g} / \mathrm{mL}$ TPCK-trypsin, and inhibitors at different concentrations. Three days post-infection, cells were washed with phosphate-buffered saline (PBS), fixed with $4 \%$ paraformaldehyde, and virus plaques were detected by immunostaining with anti-M1 antibody (diluted 1:1000 in PBS, 1\% Tween 20, $5 \%$ FBS) followed by anti-mouse horseradish peroxidase (HRP)-conjugated secondary antibody (diluted 1:1000 in PBS containing 1\% Tween 20 and 5\% FBS). Plaques were visualized using the Vector Nova-Red kit (Vector Laboratories Ltd., Peterborough, UK) and counted. The 50\% inhibitory concentration $\left(I C_{50}\right)$ was determined as the concentration at which the plaques area is reduced by $50 \%$ compared to untreated infected control. This value was calculated in both virus-induced CPE by MTS assay and immunohistochemical method in plaque reduction assay.

\subsection{Time-of-Addition Studies}

To examine the anti-influenza activity of compound 2 at different stages of the influenza life cycle, compound 2 was added overnight before virus adsorption (I), during viral adsorption for $1 \mathrm{~h}$ (II) and post-viral adsorption for $72 \mathrm{~h}$. After incubation in case of I and II, the inhibitor was removed and the cells were grown for $72 \mathrm{~h}$ in fresh medium. Cell viability was determined using MTS assay.

\subsection{SDS-PAGE and Western Blot Analysis}

MDCK cells in 12-wells plates were infected with influenza A virus $(M O I=1)$ for $1 \mathrm{~h}$ at $37^{\circ} \mathrm{C}$. The inoculum was removed and the cells were washed with serum-free medium. Fresh serum-free medium containing $2 \mu \mathrm{g} / \mathrm{mL}$ TPCK-trypsin and inhibitors at various concentrations was added for $48 \mathrm{~h}$. Cells were lysed at $4{ }^{\circ} \mathrm{C}$ for $1 \mathrm{~h}$ with TNET buffer $(20 \mathrm{mM}$ Tris- $\mathrm{HCl}(\mathrm{pH}$ 7.4), $150 \mathrm{mM} \mathrm{NaCl}$, $1 \mathrm{mM}$ EDTA, $1 \%$ Triton X-100). Proteins were separated by SDS-PAGE under reducing conditions, transferred to PVDF membranes and detected with primary rabbit polyclonal serum anti-sHA (1:500 dilution) or anti- $\beta$-actin antibody (1:1000 dilution) followed by anti-rabbit or anti-mouse peroxidase (HRP)-conjugated secondary antibodies (diluted 1:2000). Antigen-antibody complexes were detected using Super Signal West Pico Substrate system (Pierce) on the X-ray films (Fuji, Tokyo, Japan).

\subsection{Determination of Lipophilicity Parameters}

Determination of $R_{\mathrm{Mw}}$ 's of compounds $1-8$ by RP-TLC was performed using procedures which have been described elsewhere [37] and is presented in Supplementary Material Section S3.

Theoretical partition coefficients $\mathrm{X} \log \mathrm{P} 3$ of the examined compounds 1-9 were calculated using ALOGPS (version 2.1) software [38].

\subsection{Quantitative Structure-Activity Relationship Analysis}

Quantitative structure-activity relationship analysis was performed by linear regression analysis with Statistica (version 9.1). Values for coefficients in Equations (1) and (2) were found in the least 
square approach. The fitness of the model was checked by the coefficient of determination $\left(R^{2}\right)$ and standard error of the regression $\left(s_{e}\right)$. The statistical significance of the estimated parameters was checked by $F$-test and the corresponding probability value $(p)$. Values $R, R^{2}, \mathrm{~F}, s_{e}$, and $p$ are listed below Equations (1) and (2).

Supplementary Materials: Supplementary materials can be found at www.mdpi.com/1422-0067/18/8/1700/s1, references [56-62] are cited in the supplementary materials.

Acknowledgments: We thank Z. Minta and K. Smietanka from the Department of Poultry Diseases, National Veterinary Research Institute, Pulawy, Poland, for the viral strain. We are grateful to MSc Agnieszka Szymura for help in the synthesis of some compounds and to Tadeusz Bieg for NMR analysis (both from Silesian University of Technology, Gliwice, Poland). This work was supported by the Polish government's budget for science in years 2012-2014, grant No. IP2011 027271.

Author Contributions: Ewelina Krol conceived, designed, and performed the experiments, analyzed and interpreted the data, wrote the manuscript, conceived the study, acquired the funding, and supervised the research. Ilona Wandzik designed, synthesized, and characterized chemical compounds, performed correlation between $p\left[I C_{50}\right]$ and lipophilicity parameters, and described these sections in the paper. Martyna Krejmer-Rabalska helped in some experiments. Boguslaw Szewczyk revised the manuscript. All authors read and approved the final version of the manuscript.

Conflicts of Interest: The authors declare no conflict of interest.

\section{Abbreviations}

$\begin{array}{ll}\text { CC }_{50} & \text { Compound concentration required to reduce cell viability by } 50 \% \\ \text { CPE } & \text { Cytopathic effect } \\ \text { HA } & \text { Hemagglutinin } \\ \text { IC }_{50} & \text { Compound concentration required to inhibit virus plaque production by } 50 \% \\ \text { MDCK } & \text { Madin-Darby canine kidney cells } \\ \text { NA } & \text { Neuraminidase } \\ \text { S.D. } & \text { Standard deviations } \\ \text { SI } & \text { Selectivity index } \\ \text { TPCK } & \text { L-1-Tosylamide-2-phenylethyl chloromethyl ketone }\end{array}$

\section{References}

1. Miller, M.; Viboud, C.; Simonsen, L.; Olson, D.R.; Russell, C. Mortality and morbidity burden associated with A/H1N1 pdm influenza virus: Who is likely to be infected, experience clinical symptoms, or die from the H1N1 pdm 2009 pandemic virus? PLoS Curr. 2009, 1, RRN1013. [CrossRef] [PubMed]

2. McCaughey, C. Influenza: A virus of our times. Ulster Med. J. 2010, 79, 46-51. [PubMed]

3. Hayden, F.G. Antivirals for pandemic influenza. J. Infect. Dis. 1997, 176, S56-S61. [CrossRef] [PubMed]

4. Wang, C.; Takeuchi, K.; Pinto, L.H.; Lamb, R.A. Ion channel activity of influenza A virus M2 protein: Characterization of the amantadine block. J. Virol. 1993, 67, 5585-5594. [PubMed]

5. Monto, A.S.; Fleming, D.M.; Henry, D.; de Groot, R.; Makela, M.; Klein, T.; Elliott, M.; Keene, O.N.; Man, C.Y. Efficacy and safety of the neuraminidase inhibitor zanamivirin the treatment of influenza A and B virus infections. J. Infect. Dis. 1999, 180, 254-261. [CrossRef] [PubMed]

6. Nicholson, K.G.; Aoki, F.Y.; Osterhaus, A.D.; Trottier, S.; Carewicz, O.; Mercier, C.H.; Rode, A.; Kinnersley, N.; Ward, P. Efficacy and safety of oseltamivir in treatment of acute influenza: A randomised controlled trial. Neuraminidase Inhibitor Flu Treatment Investigator Group. Lancet 2000, 355, 1845-1850. [CrossRef]

7. Ison, M.G. Antivirals and resistance: Influenza virus. Curr. Opin. Virol. 2011, 1, 563-573. [CrossRef] [PubMed]

8. Luscher-Mattli, M. Influenza chemotherapy: A review of the present state of art and of new drugs in development. Arch. Virol. 2000, 145, 2233-2248. [CrossRef] [PubMed]

9. Bright, R.A.; Medina, M.J.; Xu, X.; Perez-Oronoz, G.; Wallis, T.R.; Davis, X.M.; Povinelli, L.; Cox, N.J.; Klimov, A.I. Incidence of adamantane resistance among influenza A (H3N2) viruses isolated worldwide from 1994 to 2005: A cause for concern. Lancet 2005, 366, 1175-1181. [CrossRef] 
10. Bright, R.A.; Shay, D.K.; Shu, B.; Cox, N.J.; Klimov, A.I. Adamantane resistance among influenza A viruses isolated early during the 2005-2006 influenza season in the United States. JAMA 2006, 295, 891-894. [CrossRef] [PubMed]

11. Deyde, V.M.; Xu, X.; Bright, R.A.; Shaw, M.; Smith, C.B.; Zhang, Y.; Shu, Y.; Gubareva, L.V.; Cox, N.J.; Klimov, A.I. Surveillance of resistance to adamantanes among influenza A(H3N2) and A(H1N1) viruses isolated worldwide. J. Infect. Dis. 2007, 196, 249-257. [CrossRef] [PubMed]

12. Garten, R.J.; Davis, C.T.; Russell, C.A.; Shu, B.; Lindstrom, S.; Balish, A.; Sessions, W.M.; Xu, X.; Skepner, E.; Deyde, V.; et al. Antigenic and genetic characteristics of swine-origin 2009 A (H1N1) influenza viruses circulating in humans. Science 2009, 325, 197-201. [CrossRef] [PubMed]

13. Ferraris, O.; Lina, B. Mutations of neuraminidase implicated in neuraminidase inhibitors resistance. J. Clin. Virol. 2008, 41, 13-19. [CrossRef] [PubMed]

14. Thorlund, K.; Awad, T.; Boivin, G.; Thabane, L. Systematic review of influenza resistance to the neuraminidase inhibitors. BMC Infect. Dis. 2011, 11, 134. [CrossRef] [PubMed]

15. Samson, M.; Pizzorno, A.; Abed, Y.; Boivin, G. Influenza virus resistance to neuraminidase inhibitors. Antivir. Res. 2013, 98, 174-185. [CrossRef] [PubMed]

16. Hurt, A.C.; Deng, Y.M.; Ernest, J.; Caldwell, N.; Leang, L.; Iannello, P.; Komadina, N.; Shaw, R.; Smith, D.; Dwyer, D.E.; et al. Oseltamivir-resistant influenza viruses circulating during the first year of the influenza A(H1N1) 2009 pandemic in the Asia-Pacific region, March 2009 to March 2010. Euro Surveill. 2011, 16, pii:19770.

17. Renaud, C.; Kuypers, J.; Englund, J.A. Emerging oseltamivir resistance in seasonal and pandemic influenza A/H1N1. J. Clin. Virol. 2011, 52, 70-78. [CrossRef] [PubMed]

18. Hauge, S.H.; Dudman, S.; Borgen, K.; Lackenby, A.; Hungnes, O. Oseltamivir-resistant influenza viruses A (H1N1), Norway, 2007-08. Emerg. Infect. Dis. 2009, 15, 155-162. [CrossRef] [PubMed]

19. Meijer, A.; Lackenby, A.; Hungnes, O.; Lina, B.; van-der-Werf, S.; Schweiger, B.; Opp, M.; Paget, J.; van-de-Kassteele, J.; Hay, A.; et al. Oseltamivir-resistant influenza virus A (H1N1), Europe, 2007-08 season. Emerg. Infect. Dis. 2009, 15, 552-560. [CrossRef] [PubMed]

20. Tamura, D.; Mitamura, K.; Yamazaki, M.; Fujino, M.; Nirasawa, M.; Kimura, K.; Kiso, M.; Shimizu, H.; Kawakami, C.; Hiroi, S.; et al. Oseltamivir-resistant influenza a viruses circulating in Japan. J. Clin. Microbiol. 2009, 47, 1424-1427. [CrossRef] [PubMed]

21. Orozovic, G.; Orozovic, K.; Järhult, J.D.; Olsen, B. Study of oseltamivir and zanamivir resistance-related mutations in influenza viruses isolated from wild mallards in Sweden. PLoS ONE 2014, 9, e89306. [CrossRef] [PubMed]

22. Wiley, D.C.; Skehel, J.J. The structure and function of the hemagglutinin membrane glycoprotein of influenza virus. Annu. Rev. Biochem. 1987, 56, 365-394. [CrossRef] [PubMed]

23. Colman, P. Structure and function of the neuraminidase. In Textbook of Influenza; Nicholson, K.G., Webster, R.G., Hay, A.J., Eds.; Blackwell Science: London, UK, 1998; pp. 65-73.

24. Suzuki, T.; Takahashi, T.; Guo, C.T.; Hidari, K.I.P.J.; Miyamoto, D.; Goto, H.; Kawaoka, Y.; Suzuki, Y. Sialidase activity of influenza A virus in an endocytic pathway enhances viral replication. J. Virol. 2005, 79, 11705-11715. [CrossRef] [PubMed]

25. Schulze, I.T. Effects of glycosylation on the properties and functions of influenza virus hemagglutinin. J. Infect. Dis. 1997, 176, S24-S28. [CrossRef] [PubMed]

26. Ward, C.W.; Murray, J.M.; Roxburgh, C.M.; Jackson, D.C. Chemical and antigenic characterisation of the carbohydrate side chains of an Asian (N2) influenza virus neuraminidase. Virology 1983, 126, 370-375. [CrossRef]

27. Inkster, M.D.; Hinshaw, V.S.; Schulze, I.T. The hemagglutinins of duck and human H1 influenza viruses differ in sequence conservation and in glycosylation. J. Virol. 1993, 67, 7436-7443. [PubMed]

28. Matrosovich, M.; Zhou, N.; Kawaoka, Y.; Webster, R. The surface glycoproteins of H5 influenza viruses isolated from humans, chickens, and wild aquatic birds have distinguishable properties. J. Virol. 1999, 73, 1146-1155. [PubMed]

29. Wagner, R.; Wolff, T.; Herwig, A.; Pleschka, S.; Klenk, H.-D. Interdependence of hemagglutinin glycosylation and neuraminidase as regulators of influenza virus growth: A study by reverse genetics. J. Virol. 2000, 74, 6316-6323. [CrossRef] [PubMed] 
30. Varki, A.; Cummings, R.D.; Esco, J.D.; Freeze, H.H.; Stanley, P.; Bertozzi, C.R.; Hart, G.W.; Etzler, M.E. Essentials of Glycobiology, 2nd ed.; CSHL Press: Nassau NY, USA, 2009.

31. Wandzik, I.; Bieg, T. Adducts of uridine and glycals as potential substrates for glycosyltransferases. Bioorg. Chem. 2007, 35, 401-416. [CrossRef] [PubMed]

32. Wandzik, I.; Bieg, T.; Czaplicka, M. Synthesis of 2-deoxy-hexopyranosyl derivatives of uridine as donor substrate analogues for glycosyltransferases. Bioorg. Chem. 2009, 37, 211-216. [CrossRef] [PubMed]

33. Wandzik, I.; Bieg, T.; Kadela, M. Simultaneous removal of benzyl and benzyloxycarbonyl protective groups in $5^{\prime}$-O-(2-deoxy- $\alpha$-D-glucopyranosyl)uridine by catalytic transfer hydrogenolysis. Nucleos. Nucleot. Nucl. 2008, 27, 1250-1256. [CrossRef] [PubMed]

34. Krol, E.; Wandzik, I.; Gromadzka, B.; Nidzworski, D.; Rychlowska, M.; Matlacz, M.; Tyborowska, J.; Szewczyk, B. Anti-influenza A virus activity of uridine-derivatives of 2-deoxy sugars. Antivir. Res. 2013, 100, 90-97. [CrossRef] [PubMed]

35. Bolitt, V.; Mioskowski, Ch.; Lee, S.-G.; Falck, J.R. Direct preparation of 2-deoxy-D-glucopyranosides from glucals without Ferrier rearrangement. J. Org. Chem. 1990, 55, 5812-5813. [CrossRef]

36. Paszkowska, J.; Kania, B.; Wandzik, I. Evaluation of the lipophilicity of selected uridine derivatives by use of RP-TLC, shake-flask and computational methods. J. Liq. Chrom. RT 2012, 35, 1202-1212. [CrossRef]

37. Tetko, I.V.; Gasteiger, J.; Todeschini, R.; Mauri, A.; Livingstone, D.; Ertl, P.; Palyulin, V.A.; Radchenko, E.V.; Zefirov, N.S.; Makarenko, A.S.; et al. Virtual computational chemistry laboratory-Design and description. J. Comput. Aid. Mol. Des. 2005, 19, 453-463. [CrossRef] [PubMed]

38. Dross, K.; Rekker, R.F.; de Vries, G.; Mannhold, R. The lipophilic behaviour of organic compounds: 3. The search for interconnections between reversed-phase chromatographic data and $\log \mathrm{P}$ foct values. Quant. Struct. Act. Relat. 1998, 17, 549-557. [CrossRef]

39. Li, R.; Liu, T.; Liu, M.; Chen, F.; Liu, S.; Yang, J. Anti-influenza A virus activity of dendrobine and its mechanism of action. J. Agric. Food Chem. 2017, 65, 3665-3674. [CrossRef] [PubMed]

40. Ding, Y.; Cao, Z.; Cao, L.; Ding, G.; Wang, Z.; Xiao, W. Antiviral activity of chlorogenic acid against influenza A (H1N1/H3N2) virus and its inhibition of neuraminidase. Sci. Rep. 2017, 7, 45723. [CrossRef] [PubMed]

41. Wu, W.; Li, R.; Li, X.; He, J.; Jiang, S.; Liu, S.; Yang, J. Quercetin as an antiviral agent inhibits influenza A virus (IAV) entry. Viruses 2016, 8, 6. [CrossRef] [PubMed]

42. Dong, W.; Farooqui, A.; Leon, A.J.; Kelvin, D.J. Inhibition of influenza A virus infection by ginsenosides. PLoS ONE 2017, 12, e0171936. [CrossRef] [PubMed]

43. Asano, N. Glycosidase inhibitors: Update and perspectives on practical use. Glycobiology 2003, 13, 93R-104R. [CrossRef] [PubMed]

44. Chapel, C.; Garcia, C.; Bartosch, B.; Roingeard, P.; Zitzmann, N.; Cosset, F.-L.; Dubuisson, J.; Dwek, R.A.; Trepo, C.; Zoulim, F.; et al. Reduction of the infectivity of hepatitis C virus pseudoparticles by incorporation of misfolded glycoproteins induced by glucosidase inhibitors. J. Gen. Virol. 2007, 88, 1133-1143. [CrossRef] [PubMed]

45. Durantel, D.; Branza-Nichita, N.; Carrouee-Durantel, S.; Butters, T.D.; Dwek, R.A.; Zitzmann, N. Study of the mechanism of antiviral action of iminosugar derivatives against bovine viral diarrhea virus. J. Virol. 2001, 75, 8987-8998. [CrossRef] [PubMed]

46. Lazar, C.; Durantel, D.; Macovei, A.; Zitzmann, N.; Zoulim, F.; Dwek, R.A.; Branza-Nichita, N. Treatment of hepatitis $B$ virus-infected cells with $\alpha$-glucosidase inhibitors results in production of virions with altered molecular composition and infectivity. Antivir. Res. 2007, 76, 30-37. [CrossRef] [PubMed]

47. Kohsaka, S.; Mita, K.; Matsuyama, M.; Mizuno, M.; Tsukuda, Y. Impaired development of rat cerebellum induced by neonatal injection of the glycoprotein synthesis inhibitor, tunicamycin. J. Neurochem. 1985, 44, 406-410. [CrossRef] [PubMed]

48. Bourke, C.A.; Carrigan, M.J. Experimental tunicamycin toxicity in cattle, sheep and pigs. Aust. Vet. J. 1993, 70, 188-189. [CrossRef] [PubMed]

49. Krol, E.; Wandzik, I.; Szeja, W.; Grynkiewicz, G.; Szewczyk, B. In vitro antiviral activity of some uridine derivatives of 2-deoxy sugars against classical swine fever virus. Antivir. Res. 2010, 86, 154-162. [CrossRef] [PubMed]

50. De Vries, R.P.; de Vries, E.; Bosch, B.J.; de Groot, R.J.; Rottier, P.J.M.; de Haan, C.A.M. The influenza A virus hemagglutinin glycosylation state effects receptorbinding specifity. Virology 2010, 403, 17-25. [CrossRef] [PubMed] 
51. Hebert, D.N.; Zhang, J.-X.; Chen, W.; Foellmer, B.; Helenius, A. The number and location of glycans on influenza hemagglutinin determine folding and association with calnexin and calreticulin. J. Cell Biol. 1997, 139, 613-623. [CrossRef] [PubMed]

52. Ohuchi, R.; Ohuchi, M.; Garten, W.; Klenk, H.-D. Oligosaccharides in the stem region maintain the influenza virus hemagglutinin in the metastable form required for fusion activity. J. Virol. 1997, 71, 3719-3725. [PubMed]

53. Saito, T.; Yamaguchi, I. Effect of glycosylation and glucose trimming inhibitors on the influenza A virus glycoproteins. J. Vet. Med. Sci. 2000, 62, 575-581. [CrossRef] [PubMed]

54. Wagner, R.; Heuer, D.; Wolff, T.; Herwig, A.; Klenk, H.-D. N-glycans attached to the stem domain of haemagglutinin efficiently regulate influenza A virus replication. J. Gen. Virol. 2002, 83, 601-609. [CrossRef] [PubMed]

55. Wu, Z.L.; Ethen, C.; Hickey, G.E.; Jiang, W. Active 1918 pandemic flu viral neuraminidase has distinct $\mathrm{N}$-glycan profile and is resistant to trypsin digestion. Biochem. Biophys. Res. Commun. 2009, 379, 749-753. [CrossRef] [PubMed]

56. Bello, A.M.; Poduch, E.; Fujihashi, M.; Amani, M.; Li, Y.; Crandall, I.; Hui, R.; Lee, P.I.; Kain, K.C.; Pai, E.F.; et al. A potent, covalent inhibitor of orotidine $5^{\prime}$-monophosphate decarboxylase with antimalarial activity. J. Med. Chem. 2007, 50, 915-921. [CrossRef] [PubMed]

57. Maguire, A.R.; Hladezuk, I.; Ford, A. New methods for the synthesis of N-benzoylated uridine and thymidine derivatives; A convenient method for $N$-debenzoylation. Carbohyd. Res. 2002, 337, 369-372. [CrossRef]

58. Casaschi, A.; Grigg, R.; Sansano, J.M. Palladium catalysed tandem cyclisation-anion capture. Part 6:1 Synthesis of sugar, nucleoside, purine, benzodiazepinone and $\beta$-lactam analogues via capture of in situ generated vinylstannanes. Tetrahedron 2000, 56, 7553-7560. [CrossRef]

59. Thiem, J.; Klaffke, W.; Springer, D. Selectiver aufbau $\alpha$-L-(1 $\rightarrow 4)$-verknüpfter 2,6-didesoxy-oligosaccharide. Carbohydr. Res. 1988, 174, 201-210. [CrossRef]

60. Madhusudan, S.K.; Agnihotri, G.; Negi, D.S.; Misra, A.K. Direct one-pot conversion of acylated carbohydrates into their alkylated derivatives under heterogeneous reaction conditions using solid $\mathrm{NaOH}$ and a phase transfer catalyst. Carbohydr. Res. 2005, 340, 1373-1377. [CrossRef] [PubMed]

61. Lellouche, J.-P.; Koeller, S. The particular sensitivity of silyl ethers of D-Glucal toward two vilsmeier-haack reagents $\mathrm{POCl}_{3} \cdot \mathrm{DMF}$ and $\left(\mathrm{CF}_{3} \mathrm{SO}_{2}\right)_{2} \mathrm{O} \cdot \mathrm{DMF}$. Their unique and selective conversion to the corresponding C(6)-O-formates. J. Org. Chem. 2001, 66, 693-696. [CrossRef] [PubMed]

62. Roth, W.; Pigman, W. Reactions of carbohydrates. In Methods in Carbohydrate Chemistry; Whistler, R.L., Wolfrom, M.L., BeMiller, J.N., Eds.; Academic Press: Cambridge, MA, USA, 1963; Volume 2, p. 405. 